EASTERN REVIEW 2020, T. 9

\author{
Magdalena Bogucewicz \\ (iD) https://orcid.org/0000-0002-3157-9524 \\ Adam Mickiewicz University in Poznań, Poland \\ Faculty of Political Science and Journalism \\ e-mail: magdalena.bogucewicz@gmail.com
}

\title{
The consequences of the migration crisis on the Balkan route and human rights: The current situation and prospects in Serbia
}

\begin{abstract}
This paper reflects on reports documenting human rights violations on the Balkan route as one of the implications of European migration policies, and applies them to the Serbian context. The Republic of Serbia is considered as one of the main transit countries for the migrant traffic on the Balkan Peninsula and eventually has become an unlikely gatekeeper of European Union when many migrants got stranded on its territory as a result of gradual border securitization. Further politics of closed borders have caused a serious concern of non-governmental organizations and activists when violent practices of security forces and smugglers got revealed. Serbia, in its pursuit of EU accession, must prove its respect for fundamental human rights while not losing sight of its national interest.
\end{abstract}

Keywords: migration crisis, human rights, Serbia, Balkan route, push backs.

\section{Introduction}

In 2015, hundreds of thousands of migrants began to move through Europe along the so-called Balkan route. The wars in Syria and Iraq, conflicts in Libya and Afghanistan, and the political situation in Sub-Saharan Africa forced citizens of these countries to search for safety and survival outside their homelands. As a result of the decision by Hungary to seal its borders in 2015, followed by Slovenia, Macedonia, and Croatia in 2016, migrants began to seek new routes to get into Western and Northern Europe. Consequently, many of them got stranded on the Europe's doorstep in Serbia. The European Union, the foundations of which 
are based on an undisputed respect for human rights, has to find a balance between the safety of its borders and the protection of people in need.

The problem of how the international community is to maintain a balance between humanitarianism and pragmatism has been discussed by many researchers. In Kryzys migracyjny 2015+: między solidarnościa a partykularyzmem Anna Potyrała notes that states and international organizations focus their activities on securing their own interests by limiting the influx of migrants, while refusing to help and protect them (Potyrała, 2019: 170). Political decisions made by EU member states trigger a domino effect along the Balkan migrant route, which not only strain the reception capacities and procedural systems of other countries involved, but also result in "heavy-handed responses by security forces" (Santic et al., 2017). The above-mentioned responses, including physical and mental abuse (which will be proven in further parts of this essay), seem to be supported by national governments by allowing acts of xenophobia and racism without drawing any consequences against police officers or border guards. From the perspective of human rights, Witold Klaus concludes that "asylum seekers find themselves at the receiving end of measures that infringe basic humanitarian laws and human rights and that are so inhumane, no one would ever dare deploy them on their own citizens" (Klaus, 2017).

On the one hand, Stephen Castles and Mark J. Miller predicted that the intensified migrations in today's world may contribute to the gradual degradation of nationalism, whilst on the other hand, in the event of political or economic crisis (as exemplified by the current migration crisis), the emergence of backward trends is possible (Castles, Miller, 2011). One of these backward trends is the implementation of a state-centric vision of security by the countries affected (directly or indirectly) by the migration crisis, while at the same time refusing to guarantee adequate protection in accordance with such acts of international law as the 1951 Geneva Convention Relating to the Status of Refugees, the European Convention for the Protection of Human Rights and Fundamental Freedoms of 1950 or the Charter of Fundamental Rights of the European Union.

The phenomenon of emigration is an integral part of the history of the Serbian nation. Occurring practically since the occupation of Serbian lands by the Ottoman Empire, it has accompanied Serbs through the subsequent centuries. The reason for successive waves of emigration of the Serb population was to escape from repression and persecution, including for political or ideological reasons, as well as military and economic push factors. Often, as in the case of the wave of emigration in the first half of the 1990s, these motives overlapped and it is difficult to distinguish them clearly. The sequence of their own experiences with migrations resulted in expressions of Serbs' solidarity with refugees and migrants after the first large-scale wave of irregular migration in 2015 (CeSid, 2019: 12-13). Due to its ethnic and religious setting, The Republic of Serbia (RS) can be described as a multicultural country, with a large diaspora abroad 
(Milovanović, 2019). The literature emphasizes the role of ethnicity, Orthodoxy and Slavic heritage in Serbian culture, but it also considers RS as a European state that nurtures liberal and civic values (Babić, 2012: 13). Due to such an identity dichotomy, Serbia is at a crossroads in terms of the choice of priority directions of foreign and security policy. Furthermore, as the consequence of events of the end of the 20th century, Serbia is trying to rebuild its image, for which human rights are of great importance. Aleksandar Vučić often emphasizes that the actions of the Serbian administration taken in response to the migration crisis are in line with the EU's axiology: "I think that we have acted in a very European way and that we have shown a good, human, European face to the refugees and migrants" (Aleksandar Vučić..., 2015).

In this paper, the above-quoted declaration will be confronted with reports and statements provided by representatives of third sector organizations, both national and international. The purpose of this article is to determine whether the rights of migrants have been respected during the migration crisis in Serbia. The analysis will be preceded by an overview of migration and asylum policies, and the degree of their implementation in RS. A descriptive and explanatory study of the main human rights violations will follow. Although this research is not supposed to be comparative, it will be necessary - in some cases - to refer to the overall situation in the region, in order to take into account the complexity of the migration crisis and the interdependence of countries affected by it. Prior to said analyses, the last part of the introduction will clarify the terminology used by the Author in further research.

The Republic of Serbia is considered as one of the main transit countries for migrant traffic on the Balkan Peninsula - it is estimated that in years 2015-2016, Serbia was a transit country for over a million people travelling to Western and Northern Europe (UNHCR, 2019). However, the defining of Serbia as a transit country may be dubious. A transit country is a state through which refugees and migrants travel through to reach their preferred asylum destination. It is worth noting that no transit country can be recognized as such under all and every circumstance. There might always be a number of people interested in seeking protection in that country, and the status of a country as a transit country may also change with the development of the situation in the region (Kilibarda, 2017). Since the borders of Hungary, Slovenia, Macedonia, and Croatia have been closed, the scenario in which Serbia ultimately changes its transit status to the country of enforced stay has become increasingly likely. This means that temporary solutions designed by Serbian authorities will have to be adapted to deal with the long-term stay of migrants who are unable to continue their journey.

In terms of both international law and national legislations, it's crucial to name all participants of migratory flows in a proper way and enable their status to be established. The very issue of "categorizing" participants in migratory movements, in the understanding of some researchers, deserves the name of 
"categorical fetishism", which is intended to marginalize groups that do not meet all the standards required to be asylum seekers. They emphasize how these categories are used during a crisis to provide a rationale for a policy of deterrence and exclusion. The authors argue that the dominant categories - used by both media and policymakers - do not take into account the complex factors of migration of a political, social, and economic nature (Crawley, Skleparis, 2018). In response to these gaps, Alexander Betts created the survival migrant category, which fits between the definitions of a migrant and a refugee (Betts, 2013). Another interesting division is presented by Magdalena Kmak by referring to three groups of migrants as "the Good" (highly educated third-country nationals or EU citizens), "the Bad" (migrants employed in EU states), and "the Ugly" (asylum seekers and illegal migrants) (Kmak, 2015). In accordance with Giorgio Agamben's philosophy, the last group could also be called "homines sacri" (Agamben, 2008). "Homo sacer" is a concept derived from ancient Rome and in modern times refers to those without legalized residency rights and remaining in limbo; "they exist, but their lives are of no value; they cannot be sacrificed but can be killed without committing a murder" (Pietryka, 2019). This symbolic and tangible violence does not end with the migrants themselves, but also applies to those who help them; there are arrests of volunteers and attempts are also made to criminalize aid initiatives for immigrants (see: Reggiardo, 2019; Cantat, 2019).

For this analysis, only in order to keep compliance with terms used throughout asylum procedures in Serbia, migrants were divided into three groups: refugees, migrants, and asylum seekers. According to the Geneva Convention of 1951 and the Protocol of 1967, a refugee is a person who

owing to a well-founded fear of being persecuted for reasons of race, religion, nationality, membership of a particular social group or political opinion, is outside the country of his nationality and is unable or, owing to such fear, is unwilling to avail himself of the protection of that country; or who, not having a nationality and being outside the country of his former habitual residence as a result of such events, is unable or, owing to such fear, is unwilling to return to it (UNHCR, 2010).

These documents constitute a legal basis for the granting of refugee status and describe the fundamental rights of refugees. Additionally, Article 33 includes the non-refoulment principle, which prohibits the expulsion or return of a refugee against their will to territories where their life or freedom would be threatened (UNHCR, 2010). The principle also has a broader interpretation, according to which a person applying for refugee status cannot be refused entry on the border (Potyrała, 2005: 72-73). In contrast to the determination of refugee status, which has been regulated by international law, the term "migrant" is defined by individual countries separately. The term usually denotes people who voluntarily leave their country of origin due to, for instance, economic reasons (Cymbranowicz, 2017: 53-54). The third group includes foreigners seeking asylum who are covered 
by international laws concerning protection during the processing of their applications. In its further part, the article discusses details of the asylum law and procedures as applied in Serbia.

\section{Asylum in Serbia: policies, procedures and statistics}

In the aftermath of the war in 1992-1995, in post-Yugoslav states such as Serbia, the migration crisis is a continuous and real phenomenon that has lasted for over 20 years (Krysienel, 2020: 25). In 1992 Serbia adopted the Law on Refugees and established the Commissariat for Refugees (later renamed the Commissariat for Refugees and Migration - CRM) with the main responsibility of organizing accommodation for displaced persons. After the year 2000, in pursuit of the goal of becoming an EU member state, Serbia has been gradually transforming its national policies related to migration and asylum. The 2006 Constitution of the Republic of Serbia provides for the right to asylum ${ }^{1}$ and includes the prohibition of discrimination ${ }^{2}$. The role of the CRM as the main operator of asylum centres was extended after the introduction of the Law of Asylum in 2007, Alien Law in 2008 and eventually the Law on Asylum and Temporary Protection (LATP), adopted in March 2018 (Stojic Mitrovic, 2018). The LATP amended the Serbian asylum system as part of EU accession negotiations commitments, reflecting the structure and procedures set out in the EU asylum acquis.

The crucial role of the EU's influence in Serbia is visible not only through the legislative changes but also by financial mechanisms which supported the country's response to the refugee crisis. The European Commission indicates that over $€ 80$ million has been provided to Serbia between 2015 and 2017 in the form of EU migration-related funding, which means that the EU has been the largest contributor of emergency aid in this country (European Commission, 2017). Additionally, in response to the increase of migratory flows in 2015, the Serbian government established the Working Group on Mixed Migration Flows, which involved the representatives from the Ministries of Labor, Employment, Veteran and Social Affairs, Interior, and Health; as well as the Ministry of EU integration. The Group also cooperates with the KIRS and EU Delegation in Serbia, with the

1 "Any foreign national with reasonable fear of prosecution based on his race, gender, language, religion, political opinions, national origin or association with some other group, shall have the right to asylum in the Republic of Serbia" - Constitution of the Republic of Serbia. 2006, Article 57.

2 "Persons belonging to national minorities shall be guaranteed equality before the law and equal legal protection. Any discrimination on the grounds of affiliation to a national minority shall be prohibited" - ibidem, Article 76. 
main task of providing humanitarian aid to migrants (Santic et al., 2017: 225). Therefore, migration management has become one of the priorities for European and Serbian authorities. The first step to effective organization is to examine whether a person qualifies for refugee status or not; the main tool to decide on that matter is an effective asylum procedure.

The asylum procedure in Serbia is regulated by the Law on Asylum and Temporary Protection which came into force in June 2018. A foreigner wishing to seek asylum in Serbia may express such intention within Serbian territory or at border crossings before an authorized police officer. As a proof of expressing such intention, a foreigner receives a certificate, then has to check-in at a designated asylum centre within 72 hours and make an official asylum application. The Asylum Office (first-instance authority) is obligated to make a decision on the application within 3 months (AIDA, 2019). In practice, migrants are often not informed properly about their rights or denied access to further procedures (Petrović, 2020).

In response to intensified migratory flows, the Serbian government established Asylum Centres (AC) and Reception/Transit Centres (RTC) throughout the RS, coordinated by the previously mentioned CRM. Due to the European integration process, accommodation provided to migrants has to be in accordance with the EASO standards (see: EASO, 2016). There are currently 14 RTCs in Serbia and 11 of them were active in $2019^{3}$, with a total capacity of 3,240 persons (Petrović, 2020). Asylum Centres have been created for migrants applying for asylum, whereas Reception Centres are for the short-term stay of migrants who intend to continue their journey and treat Serbia as a transit state. Rooms in Reception Centres are usually fitted with more than 30 beds and are tailored to accommodate foreign nationals for a short period. With the closure of the Balkan route, which consequently prevented the further movement of migrants in Serbia, these Centres became places of long-term stay (Belgrade Centre for Human Rights, 2017, C). It has to be noted that not all migrants staying in Serbia use the infrastructure provided by the authorities. The Amnesty International report shows that in January 2018 approximately 1,800 migrants resided in abandoned warehouses where the temperature often dropped below $0^{\circ} \mathrm{C}$. Eventually, they were forced to transfer to government Centres which low standards and overcrowding prevented the fulfilment of their essential social needs (Amnesty International, 2018). This information is also confirmed by the Belgrade Center for Human Rights which indicates that the majority of Asylum Centres in Serbia are overcrowded and do not provide sufficient sanitary conditions (Belgrade Centre for Human Rights, 2017, A). Many migrants still choose to find shelters in old warehouses or along the border with Croatia, often accommodated in tents or other provisional housings.

3 The RTCs in Preševo, Dimitrovgrad and Divljan were inoperative during 2019 due to cost-cutting efforts. 
Table 1. The number of migrants expressing an intention to seek asylum in Serbia in 2008-2019

\begin{tabular}{|c|c|}
\hline Year & $\begin{array}{c}\text { Number of people expressing an } \\
\text { intention to seek asylum in Serbia }\end{array}$ \\
\hline 2008 & 77 \\
\hline 2009 & 275 \\
\hline 2010 & 522 \\
\hline 2011 & 3,132 \\
\hline 2012 & 2,723 \\
\hline 2013 & 5,066 \\
\hline 2014 & 16,490 \\
\hline 2015 & 577,995 \\
\hline 2016 & 96,117 \\
\hline 2017 & 6,199 \\
\hline 2018 & 8,436 \\
\hline 2019 & 12,937 \\
\hline
\end{tabular}

Source: Author based on Petrović, 2020: 14.

In 2019, 12,937 migrants expressed their intention of seeking asylum in Serbia. The largest groups were Afghans $(3,847)$, Pakistanis $(2,766)$, Syrians $(1,976)$ and Iraqis $(1,560)$. The Ministry of the Interior (MI) confirms the intention to grant asylum by issuing a certificate which allows migrants to benefit from assistance centres, where their basic needs can be satisfied, including accommodation, food, and medical and psychological care. In 2019, only 254 persons of over 12,000 made further asylum applications, which means that only a minor percentage of migrants was genuinely interested in receiving asylum in Serbia and the majority of them used certificates to move freely in and around Serbia, treating the RS as a transit zone (Petrović, 2020). Refugee status was granted to 17 persons and another 18 applicants received subsidiary protection in 2019 (AIDA, 2020). On the basis of the above findings, migrants in Serbia can be classified into four groups (number of migrants in each category in brackets; the data refers to procedures in 2019 and are not accumulated with those of previous years):

- migrants expressing their wish to seek asylum $(12,937)$,

- migrants seeking asylum (254),

- migrants who are granted refugee status (17),

- migrants who received additional protection $(18)^{4}$.

${ }^{4}$ The Serbian asylum law distinguishes between the status of a refugee and a person benefiting from additional protection: "A refugee shall be understood to mean a foreigner who, owing to a well-founded fear of being persecuted for reasons of race, sex, language, religion, nationality, or membership of a particular social group, or political opinion, is outside the country of his/her origin, 
The current migratory flow in the Republic of Serbia decreased significantly after the explosion of arrivals in 2015 and 2016 (see: Table 1). Nonetheless, the number of asylum seekers has increased gradually again since 2018, which is caused mainly by the closure of international borders and results in a growing number of migrants stranded in the Balkans. The situation on the Route is already changing while this essay is being written and the new dynamics (collapse of EU-Turkey deal and COVID-19 pandemic) will shape further developments in this region.

\section{Dangerous game: push backs and smugglers}

The securitarian turn in European migration policy had many practical repercussions for Serbia. Consequently, it has also affected the rhetoric about migrants coming from the MENA region. The discourse entitled "we were refugees too" from the beginning of the migration crisis has shifted to "Serbia is not, and cannot be, a parking lot for everyone" (Vučić o migrantima..., 2020). These narratives opened the door for practices which are not in line with neither fundamental human rights nor the values of the European Union.

From the migrants' perspective, stricter border controls along the Balkan Route created significant difficulties in further migratory movement and made the passage more dangerous. Médecins Sans Frontières reported that from January to June 2017, 78 migrants died while trying to pass through the borders of Turkey, Serbia, Croatia and Hungary. According to data collected from the media, non-governmental organizations and public authorities, deaths were caused by drowning (38), car accidents (12), hypothermia (7) and suicide (4) (MSF, 2017). The self-organized attempts to cross the border are called a game: "If you go, you succeed. If you don't go, you lose. That's why they call it a game," says a 20-years old Afghan migrant who reached Serbia after three games (Taylor, Cardi, 2017). Major dangers faced by migrants attempting to cross the border on the Balkan route come from two groups: police officers and smugglers.

The previously described asylum procedure in Serbia starts with a foreigner's expression of an intent to seek asylum, made by in front of an authorized police

and is unable or, owing to such fear, is unwilling to avail himself/herself of the protection of that country, as well as a stateless person who is outside the country of his/her habitual residence, and who is unable or owing to such fear, unwilling to return to that country". "Subsidiary protection shall be understood to mean a form of protection granted by the Republic of Serbia to a foreigner who would be, if returned to the country of his/her origin or habitual residence, subjected to serious harm, and who is unable or unwilling to avail himself/herself of the protection of that country, in accordance with Article 25 of this Law"; more in: Law on Asylum..., 2018. 
officer. It is very important to emphasize that communicating this intention not only provides the basis for the aid, but it also confers the right to remain in the territory of a given country, which protects a migrant from the so-called push back. The term pushes back is used to describe practices applied by authorities that prevent aliens from applying for protection on the territory of a country by the compulsory expulsion of migrants to another country. By expelling those who seek safety and dignity abroad, a state waives its responsibility to examine individual cases. This is not consistent with the Universal Declaration of Human Rights ${ }^{5}$ and the European Convention on Human Rights ${ }^{6}$. Expulsions violate international and EU laws, since they undermine the right of migrants to seek asylum, and refuse people the right to a fair trial before a decision is taken to expel them. Finally, they carry the risk of sending refugees, and other people in need of international protection, back to locations where their life or health are threatened.

Aid organizations pay special attention to the humanitarian situation in Croatia and Hungary since there the rights of migrants are most often violated. Although little has been said about Serbia, when in fact the country attracts cohorts of migrants after they fail to cross borders. Moreover, the abusive behaviour of the security forces and smugglers has also become a common practice in this country. According to local NGOs, on the border of Serbia in 2017, the authorities recorded 110 illegal expulsions of more than 850 migrants and 52 cases involving minors (Hall, Pantovic, 2018). In its report, Oxfam describes a number of abusive behaviours, of which two are selected to illustrate the practices of police officers in Serbia:

1. On 17 December 2016, an unidentified group of uniformed officials stopped a bus with seven Syrians of Kurdish origin who were officially registered in one of the local Asylum Centres. The migrants, including a 16 years-old girl unaccompanied by an adult and a 2 years-old child, were dragged from the bus and taken to a police car. In the middle of the night, the group was transported to a forest and left there despite temperature being $-11^{\circ} \mathrm{C}$. One of the group's members used GPS and managed to locate the group and contact Info Park, an organization that provides assistance to refugees in Serbia. The group was saved with the help of activists and a local police officer from a nearby village. Two victims suffered from hypothermia and lost consciousness (OXFAM, 2017).

2. At night between 2 and 3 February 2017, a group of Afghans crossed the border of Serbia and succeeded in registering as asylum seekers at a court in Pirot, Serbia. After receiving their certificates, they were taken by police officers to be transferred to an assigned aid centre. After 90 minutes of driving, the officers

${ }^{5}$ Article 14 of the Universal Declaration of Human Rights reads: "Everyone has the right to seek and to enjoy in other countries asylum from persecution" (Bierzanek, Symonides, 2005: 265).

${ }^{6}$ Protocol 4, Article 4 of the European Convention on Human Rights: "Collective expulsion of aliens is prohibited" (Grzymkowska, 2015: 66). 
abandoned the group in the forest and destroyed their certificates. After spending the whole night in the cold, the group of migrants realized that they had been taken to Bulgaria. After further action taken by officials, they were taken back to Serbia on 10 February. One of the group's female members had to be taken to hospital as a result of injuries and fatigue (OXFAM, 2017).

A further part of the report based on interviews with 140 migrants (100 staying in Serbia and 40 in Macedonia) confirms numerous cases of abuse by state officials, not only in Serbia:

- Hungarian officers forced migrants to undress and sit in the snow while pouring cold water onto them;

- Bulgarian police officers confiscated migrants' belongings, including shoes, before they were pushed back behind the border;

- Croatian police officers forced a group of migrants to undress, took their clothes and shoes, and requested them to walk along a railway track back to Serbia. Migrants also had to pass a row of 10 officers who stood along the track and beat migrants with batons.

Even when it's not clear if migrants have expressed their intention to seek asylum or not, violent acts of police officers should not take place. One of many examples included in the Human Rights Watch report concerns a 16-year-old Afghani boy travelling alone as his parents had died in Afghanistan:

I tried to cross the Hungarian border when the Serbian police caught me. They asked me to give them money. They took $€ 100$ from me and my two mobile phones. But, then one of the police officers said he wouldn't let me cross even though I gave them money. He started kicking me. He was kicking me in my ribs and in my legs. He was shouting, "fuck you" and "no border" in English while he was kicking me. I fell down on the ground. I was on the ground and he was still kicking me. Then, another police officer grabbed the collar of my jacket and pulled me up. Then they searched my clothes and took all the money I had (Human Rights Watch, 2015).

In the case of expulsion, civil and police officers often instruct migrants to move along railway tracks in the dark and leave the country - even if migrants have expressed their intention to receive asylum. One of the most tragic expulsion cases involved 6 years-old Medina who died on tracks shortly after she and her family were expelled on the border of Serbia and Croatia (Zebić, 2017). According to representatives of Médecins Sans Frontières, in 2017, seven people (including three children) died in the area of the same border crossing on the railway line between Tovarnik (Croatia) and Šid (Serbia), as they were hit by trains or electrocuted (Zivanovic, 2017). As a consequence, migrants deprived of hope and strength after multiple attempts to cross the border on their own turn to smugglers.

Nowadays, the term the Balkan Route is associated mostly with a passage for migration flows; however, after the disintegration of Yugoslavia, this route served as a channel for transnational arms and drugs smuggling operations (UNODC, 
2015). Therefore, a network of organizations engaged in criminal activities related to smuggling and trafficking already existed in the region and could adapt easily to the new demand for illegal services after border closures. In 2016, in Serbia alone, 6,050 people were seized on borders and 349 allegations of trafficking were pressed against 604 perpetrators who attempted to smuggle 5,181 people. In 2017 , the number of people stopped at the border was 2,638; 161 criminal charges were pressed against 269 perpetrators who attempted to smuggle 1,188 foreigners. Migrant trafficking networks in Western Balkan countries remain active and continue to smuggle migrants (European Commission, 2018).

Depending on the means of transport, the risk involved, or season, the price for smuggling varies from 1,500 to 3,000 EUR (Dimitriadi et al., 2016). For comparison, Reuters indicated that the rates may reach 3,500-5,000 EUR. In the latter case, the smuggling includes the flight from Istanbul to Sarajevo or Podgorica, then a trip to Croatia and to Western European countries (Zuvela, 2017). According to the MSF branch in Serbia, the cost of smuggling from Afghanistan to Italy is approximately 5,000 to 7,000 EUR (MSF, 2017). It is estimated that prices increased on average $33 \%$ after securitarian measures were implemented by the EU in 2015 and 2016. This means that anti-smuggler repressions made the illegal practices more lucrative for smugglers (Mandic, 2017). Nonetheless, migrant journeys became riskier and in the further hunt for profits, the modus operandi of smugglers can reach higher levels of danger.

Surprisingly, according to an MSF report, the authorities pose a greater risk for migrants than smugglers. Based on information collected from underage migrants taken care of by this organization, only $8 \%$ of reported cases of fraud and abuse were committed by smugglers. At the same time, as much as $76 \%$ of reports point to the authorities as perpetrators (MSF, 2017). From April to July 2016, the MSF helped 188 migrants who went through traumatic situations, such as ill-treatment and torture, imprisonment, kidnapping and sexual violence by smugglers or the police. Of those people, including women and children, $65 \%$ were reported to have experienced physical violence from police officers and 35\% claimed that they had experienced aggression from others (e.g. smugglers or other migrants (MSF, 2016)). In 2016, OXFAM documented 77 expulsions, totalling 1,411 migrants, from Serbia to Bulgaria (OXFAM, 2017). For comparison, from July to December 2016, Hungarian officers at the border with Serbia refused entry and the possibility to seek asylum to 19,219 migrants, frequently resorting to physical violence. The refusal also applied to those coming from war zones in such countries as Syria, Iraq, and Afghanistan (Voynov et al., 2017). As time goes by, these practices continue - in 2019, Serbian MSF treated 116 patients for intentional physical violence; 104 of them reported that the perpetrators were either border or state authorities (MSF, 2020). It seems that violations perpetrated by smugglers, compared to these committed by police officers, are not only less frequent, but also less violent; they include minor theft, or lying about standards of transportation 
and accommodation along the route. Similarly interesting is the study conducted by Danilo Manic, who describes migrant-smuggler relations as based on trust and mutual understanding. Furthermore, most of the Syrian respondents taking part in this survey (over 73\%) were "very satisfied" with cooperation with their criminal ally (Mandic, 2017). Nevertheless, abuse and human rights violations from both police officers and smugglers rise an equally serious concern, particularly when minors are on the receiving end.

\section{Unaccompanied minors}

One of the most vulnerable groups of migrants exposed to human rights violations on the Balkan Route is unaccompanied children. In Serbian legislation (LATP) an unaccompanied minor is understood as a "foreigner under 18 years of age who was not accompanied by their parents or the guardians, nor an adult who is responsible for them, on their arrival to the Republic of Serbia" (Law on Asylum..., 2018: Article 2). Ratification of the Convention on the Rights of the Child and the optional protocols with the Convention obligate Serbia to take responsibility for the special care of all children under its jurisdiction, including child refugees or migrants. Furthermore, the Law on Asylum and Temporary Protection introduces the principle of the best interest of the minor (Article 10), requires the appointment of a guardian to an unaccompanied minor (Article 12) and gives priority to processes related to unaccompanied minors (Article 12). While the legal framework seems to be at a high level and in line with international standards, the provisions guaranteeing the protection of minors are not always respected. In practice, guardians are appointed too late, the decision-making process regarding asylum applications is excessively long and many children stay in informal refugee settlements, outside of the protection system.

According to the Belgrade Centre for Human Rights, in Serbia, in 2016, 5,390 children sought asylum, including 177 unaccompanied minors (Krasic et al., 2017). In the middle of 2018, the number of children was 682, of which 75 minors were unaccompanied by adults (Zivanovic et al., 2018). These figures do not match with those included in the report by the Council of the European Union, which estimated that in 2016 in Serbia more than 1,000 unaccompanied children were identified and many of them stayed in the centre of Belgrade in very difficult living conditions (Council of Europe, 2017). During the first six months of 2019, the Belgrade branch of Save the Children helped 1,842 underaged migrants, including those who travelled unaccompanied by adults. According to the reports by the organization, $40 \%$ of unaccompanied minors were victims of illegal expulsions and one-third of them reported the use of violence by government 
officials during the process - the police and border guards humiliated them using various forms of verbal and physical violence, threatening, sneering, seizing valuables and personal items, destroying their phones, and ignoring attempts at filing asylum applications. Minors reported that they were not asked about their age and were treated as adults, although every fifth child who claimed to have been returned at the border was 13 or less; and $12 \%$ alleged acts of violence involved children in this particular age group (Save the Children, 2019).

Children unaccompanied by adults come mostly from countries with widespread violence, such as Afghanistan, Syria and Iraq. Based on interviews conducted by the Belgrade Center for Human Rights, in the period of July 2016 to May 2017, the vast majority of minors ultimately failed to seek asylum and merely expressed such an intention only to formalize their temporary stay in Serbia. Compared to statistics from 2015 (25,000 children, including 5,753 without adult care (Save the Children, 2015)), it may seem that the crisis has been averted. However, this most susceptible social group still struggles with brutal treatment by the police and traffickers, while trying to pass dangerous mountainous and forest areas at night in temperatures below $0^{\circ} \mathrm{C}$. European Union authorities have confirmed that all children without adult care who stayed in the Obrenovac Center, Belgrade, repeatedly tried to cross the border with Croatia and Hungary using services provided by smugglers (Council of Europe, 2017).

The 2017 report by the European Council draws attention to the fact that the age of children is often recorded at random, which in some circumstances leads to accommodating boys below 18 with adult men. Tomáš Boček, the Special Representative of the Secretary General for Migration and Refugees in Serbia, warns that it raises serious concerns about the exposure of children to violence and sexual exploitation (Council of Europe, 2017). Activists from the Info Park, a previously mentioned Serbian NGO, claim that young boys are particularly vulnerable to exploitation by smugglers: "They adopted a practice of renting houses in Belgrade and other parts of Serbia and locking people in flats until their family sends additional money." After interviews with migrants and refugees, employees of the Info Park confirm that minors are taken also advantage of by other migrants and local Serbs. Most often boys of Afghan or Pakistani origin are the victims, because their financial resources are scarce and they need to sacrifice more to continue their journey through Europe (Janaurova, 2018). Jelena Besedic from the Save the Children Serbia warns that despite reduced migrant traffic, minors still remain at a huge risk:

It's simply a more dangerous route, especially for children. The EU-Turkey deal has given smugglers a firmer grip on a hugely profitable business, incorporating increasingly dangerous tactics to circumvent authorities. We are seeing injuries such as dog bites and people wounded by brutal treatment as they are pushed back (Save the Children, 2017). 
The situation didn't get better in 2019 when the Centre for the Protection of Victims of Trafficking in Human Beings identified 15 migrant children as alleged victims of human trafficking (Petrovic, 2020: 131) and an Afghani boy was killed in one of the Asylum Centres (Belgrade Centre for Human Rights, 2019; Cucić: Ubijeni migrant..., 2019). It is estimated that the overall number of unaccompanied children in Serbia exceeded 3,000 in 2019 and temporary legal guardians worked with only approx. 1,300 of them (AIDA, 2020).

Despite the changes and improvements in asylum law introduced by the RS in 2018, the situation of unaccompanied children in 2019 didn't seem to improve. As long as children are placed in ACs and RTCs together with adults, while not supported by properly trained guardians, their perspectives of entering adulthood in a decent manner are unlikely. While not offered proper support from state authorities, children turn to smugglers, risking being victims of human trafficking, exploitation and other forms of abuse. On the other hand, based on reports on violent push backs, it is not surprising that minors don't trust the authorities and prefer to turn to criminal agents instead. The abusive practices of border control officers are clearly supposed to discourage migrants from further attempts at crossing, however applying them to minors as well, deserves strong condemnation and punitive consequences.

\section{Conclusions}

Like most other crises involving refugees, the migration crisis along the Balkan route is the result of a compromise between the necessity to respect international human rights and the desire to protect national interests. The lack of effective solutions results mainly from the fact that individual states avoid fulfilling their commitments, and often violate fundamental human rights and international law. Migrants are pushed back to Serbia after multiple attempts to get to neighbouring countries. The further escalation of the closed borders policy may generate a rebellious attitude among migrants who struggle against misinformation, discrimination and helplessness. Moreover, they might become aggressive to others and to each other as well - psychologists from the MSF report that instances of illnesses, such as depression, PTSD and anxiety, have been growing among migrants as the crisis continues (Squires, 2017).

Migrants coming to Serbia lack essential information about the possibilities of gaining international protection in the Balkans and encounter difficulties in their contact with government authorities. Many of them have obtained certificates confirming their intention to apply for international protection, but they failed to submit asylum applications because their ultimate goal is to reach other European countries. Thus, the vast majority of migrants stay in Serbia for several months, 
or even years, without any formal legal status, while awaiting the opportunity to cross the border with Hungary or Croatia. The critical situation of migrants is regularly taken advantage of by smugglers. However, this criminal activity is not the only threat to migrants. Humanitarian organizations meticulously record incidents of violence against migrants carried out by police officers and other public officials. "Push backs" are often the norm, practised by public officials on migrants applying for asylum. Such a practice is a clear infringement of the Universal Declaration of Human Rights and the European Convention on Human Rights. The truthfulness of migrants and activists reporting expulsions and frauds might be debatable, although evidence in the form of pictures ${ }^{7}$, recordings from hidden cameras ${ }^{8}$, and confirmation by top state authorities ${ }^{9}$, leave no doubt that violations of human rights take place on the Balkan route.

Serbia, which in 2012 received the official status of a candidate state for EU membership, needs to meet not only the formal conditions set by the Union but also meet the standards of the EU's axiology. Article 2 of the Treaty on European Union defines fundamental values of the organization and it deserves to be quoted in full:

The Union is founded on the values of respect for human dignity, freedom, democracy, equality, the rule of law and respect for human rights, including the rights of persons belonging to minorities. These values are common to the Member States, in a society in which pluralism, non-discrimination, tolerance, justice, solidarity and equality between women and men prevail (Consolidated version..., 2012).

It is worth emphasizing, however, that EU member states, such as Hungary, Croatia, and Bulgaria, are guilty of gross negligence themselves.

Despite efforts by Serbian authorities, humanitarian organizations and local NGOs, the rights of migrants are repeatedly violated, not only by smugglers, but also by local police officers and government officials in neighbouring countries. Whilst perpetrators encounter often impunity and general approval; beatings, theft, and the property damage are the migrants' reality. It is also worrying that a large number of minors arriving in Serbia unaccompanied by adults are particularly vulnerable to exploitation and violence. Furthermore, the continued stigmatization and marginalization of asylum seekers obstruct or prevent the integration of migrants with local communities, especially for those who choose to, or are forced to remain in Serbia.

${ }^{7}$ Meticulous reports containing pictures of injuries can be found on the website of the Border Violence Monitoring, 2019.

8 The recording can be viewed on the website of a UK newspaper The Guardian: Tondo, 2018.

9 The President of the Republic of Croatia, Ms. Grabar-Kitarović, confirmed that Croatian officers are responsible for expulsions, including the use of force: Walker, 2019. 
The European Commission has recommended for several years that Serbia prepares anaction plan, due to the change of the migration situation. In connection with illegal expulsion cases, Serbs should develop a firm scheme for the return of migrants and increase their ability to respond to the specific needs of unaccompanied minors (European Commission, 2017). One may suspect that with further sealing and closing of borders a large number of migrants will unintentionally remain in Serbia. The majority of them, however, do not want to give up their European Dream, regardless of threats involved, since they flee from war, persecution, and poverty. For them, every possible solution is worth trying and each risk worth taking.

\section{References}

Agamben, G. 2008. Homo Sacer. Warszawa: Wydawnictwo Prószyński i S-ka SA.

AIDA. 2019. Short Overview Asylum Procedure, http:/www.asylumineurope.org/reports/ country/serbia/short-overview-asylum-procedure (accessed 20.11.2019).

AIDA. 2020. Serbia. Country Report, https:/www.asylumineurope.org/reports/country/ serbia, (accessed 1.09.2020).

Aleksandar Vučić: 'Serbia has become one of the pillars of stability in the Balkan'. 2015, https://www.coe.int/en/web/portal/full-news/-/asset_publisher/y5xQt7QdunzT/ content/aleksandar-vucic-serbia-has-become-one-of-the-pillars-of-stability-in-thebalkan-?_101_INSTANCE_y5xQt7QdunzT_languageId=en_GB (accessed 1.09.2019).

Amnesty International. 2018. Serbia 2017/2018, https://www.amnesty.org/en/countries/ europe-and-central-asia/serbia/report-serbia/ (accessed 1.01.2019).

Babić, M. 2012. Aporie tożsamości. Serbowie, Chorwaci i Unia Europejska. In: M. Babić, F. Gołembski (eds.). Problemy aksjologiczne w relacjach Unii Europejskiej z Bałkanami. Warszawa: Instytut Europeistyki, Wydział Dziennikarstwa i Nauk Politycznych Uniwersytetu Warszawskiego, pp. 101-129.

Belgrade Centre for Human Rights. 2017. A. Country report: Serbia, Conditions in reception facilities, https://www.asylumineurope.org/reports/country/serbia/conditions-receptionfacilities (accessed 1.01.2019).

Belgrade Centre for Human Rights. 2017. C. Country report: Serbia, Types of accommodation, https://www.asylumineurope.org/reports/country/serbia/types-accommodation (accessed 1.01.2019).

Belgrade Centre for Human Rights. 2019. Right to Asylum in the Republic of Serbia. Periodic Report for January-June 2019, http://www.bgcentar.org.rs/bgcentar/eng-lat/ wp-content/uploads/2019/08/Periodic-report-Right-to-Asylum-in-Serbia-JanuaryJune-2019.pdf (accessed 1.09.2020).

Betts, A. 2013. Survival Migration: Failed Governance and the Crisis of Displacement. Ithaka: Cornell University Press.

Bierzanek, R., Symonides, J. 2005. Prawo międzynarodowe publiczne. Warszawa: LexisNexis.

Border Violence Monitoring. 2019, https://www.borderviolence.eu/violence-reports/ (accessed 1.09.2019). 
Cantat, C. 2019. The Rise and Fall of Migration Solidarity in Belgrade: Marginalising Solidarity and Institutionalising Aid. In: C. Cantat, E. Sevinin, E. Maczyńska, T. Birey (eds.). Challenging the Political Across Borders: Migrants' and Solidarity Struggles, CEU CPS Books Series, pp. 163-189.

Castles, S., Miller, M.J. 2011. Migracje we współczesnym świecie. Warszawa: Wydawnictwo Naukowe PWN.

CeSid. 2019. Stavovi građana prema uticaju izbegličke i migracione krize u 19 jedinica lokalne samouprave u Srbiji, https://www.rs.undp.org/content/serbia/sr/home/ library/poverty/stavovi-gra_ana-prema-uticaju-izbeglike-i-migracione-krize-u-19-. html (accessed 1.09.2020).

Consolidated version of the Treaty on European Union, https://eur-lex.europa.eu/ resource.html?uri=cellar:2bf140bf-a3f8-4ab2-b506-fd71826e6da6.0023.02/ DOC_1\&format=PDF (accessed 1.01.2019).

Constitution of the Republic of Serbia. 2006. Official Gazette of the Republic of Serbia 83.

Council of Europe. 2017. Report of the fact-finding mission by Ambassador Tomáš Boček, https://search.coe.int/cm/Pages/result_details.aspx?ObjectId=090000168075e9b2\#_ Toc494960694 (accessed 3.01.2019).

Crawley, H., Skleparis, D. 2018. Refugees, migrants, neither, both: categorical fetishism and the politics of bounding in Europe's 'migration crisis'. Journal of Ethnic and Migration Studies 44: 1, pp. 48-64.

Cucić: Ubijeni migrant mesecima maltretirao druge, http://rs.nlinfo.com/Vesti/a489977/ Komesar-za-izbeglice-o-ubistvu-migranta.html (accessed 1.09.2020).

Cymbranowicz, K. 2017. Europa (bez granic) - w poszukiwaniu rozwiązania kryzysu migracyjnego w Unii Europejskiej. In: H. Tendera-Właszczuk, W. Bąba, M. Zajączkowska (eds.). Nowe perspektywy integracji europejskiej w obliczu wyzwań i zagrożeń. Warszawa: Difin SA, pp. 48-79.

Dimitriadi, A., Petreska, E., Rácz, K., Simic, I. 2016. Study on smuggling of migrants, https://ec.europa.eu/home-affairs/sites/homeaffairs/files/case_study_5_greece_-_former_yugoslav_republic_of_macedonia_-_serbia_hungary.pdf (accessed 1.01.2019).

EASO. 2016. EASO Guidance on Reception Conditions: Operational Standards and Indicators, https://www.easo.europa.eu/sites/default/files/EASO $\% 20$ Guidance $\% 20$ on $\% 20$ reception $\% 20$ conditions $\% 20-\% 20$ operational $\% 20$ standards $\% 20$ and $\% 20$ indicators \%5B3\%5D.pdf (accessed 1.09.2020).

European Commission. 2017. EU announces additional emergency aid to help refugees in Serbia, https://ec.europa.eu/commission/presscorner/detail/en/IP_17_3730 (accessed 1.09.2020).

European Commission. 2018. Serbia 2018 Report, https://ec.europa.eu/neighbourhoodenlargement/sites/near/files/20180417-serbia-report.pdf (accessed 4.01.2019).

Grzymkowska, M. 2005. Prawa człowieka. Bielsko-Biała: Wydawnictwo STO.

Hall, R., Pantovic, M. 2018. Migrants stuck in Serbia play a desperate 'game'to reach the $E U$, https:/www.pri.org/stories/2018-01-03/migrants-stuck-serbia-play-desperategame-reach-eu (accessed 1.01.2019).

Human Rights Watch. 2015. Serbia: Police Abusing Migrants, Asylum Seekers, https:// www.hrw.org/news/2015/04/15/serbia-police-abusing-migrants-asylum-seekers (accessed 1.01.2019). 
Janaurova, B. 2018. 'No Guardian': Child Refugees at Risk in Serbia, http://www. balkaninsight.com/en/article/no-guardian-child-refugees-at-risk-in-serbia-09-04-2018 (accessed 4.01.2019).

Kilibarda, P. 2017. Obligations of transit countries under refugee law: A Western Balkans case study. International Review of the Red Cross 99(904), pp. 211-239.

Klaus, W. 2017. Closing Gates to Refugees: The Causes and Effects of the 2015 "Migration Crisis" on Border Management in Hungary and Poland. Yearbook of the Institute of East-Central Europe 15(3), pp. 11-34.

Kmak, M. 2015. "The Ugly" of EU Migration Policy: The role of the Recast Reception Directive in Frag- mentation of the Refugee Subject. In: D.A. Gozdecka, M. Kmak (eds.). Europe at the Edge of Pluralism. Cambridge: Antwerp and Portland: Intersentia Publishing, pp. 87-91.

Krasić, B., Milić, N., Šahović, V. 2017. Unaccompanied and Separated Children in Serbia. Belgrade: Belgrade Centre for Human Rights.

Krysienel, K. 2020. Bośnia i Hercegowina wobec kryzysu imigracyjnego na Batkanach. In: K. Cebul, R. Zenderowski (eds.). Państwa Europy Środkowej i Bałkanów wobec kryzysu migracyjnego. Warszawa: CeDeWu, pp. 25-40.

Law on Asylum and Temporary Protection of the Republic of Serbia. 2018. Official Gazette 24.

Mandic, D. 2017. Trafficking and Syrian Refugee Smuggling: Evidence from the Balkan Route. Social Inclusion 5(2), pp. 28-38.

Milovanović, M. 2019. Dva miliona Srba u dijaspori: Prosečna starost osoba koje odlaze je 34,7 godina, a najveći broj živi u Americi, https://www.nedeljnik.rs/dva-miliona -srba-u-dijaspori-prosecna-starost-osoba-koje-odlaze-je-347-godina-a-najveci-broj -zivi-u-americi/ (accessed 1.12.2020).

MSF. 2016. Sharp increase in violence against migrants since border closures in the Balkans, https://www.msf.org/serbia-sharp-increase-violence-against-migrants-border-closuresbalkans (accessed 1.01.2019).

MSF. 2017. Serbia: Games Of Violence, https:/www.msf.org/sites/msf.org/files/serbiagames-of-violence-3.10.17.pdf (accessed 1.01.2019).

MSF. 2020. International Activity Report: Balkans, https://www.msf.org/internationalactivity-report-2019/balkans (accessed 1.09.2020).

OXFAM. 2017. A Dangerous 'Game': The pushback of migrants, including refugees, at Europe's borders, https://www-cdn.oxfam.org/s3fs-public/file_attachments/bpdangerous-game-pushback-migrants-refugees-060417-en_0.pdf (accessed 1.01.2019).

Petrović, L. 2020. Right to Asylum in The Republic of Serbia 2019. Belgrade: Belgrade Centre for Human Rights.

Pietryka, M. 2019. Kryzys migracyjny jako stan wyjątkowy. Colloquium Wydziału Nauk Humanistycznych i Społecznych AMW 2, pp. 47-66.

Potyrała, A. 2005. Współczesne uchodźctwo. Próby rozwiązania międzynarodowego problemu. Poznań: Wyższa Szkoła Nauk Humanistycznych i Dziennikarstwa.

Potyrała, A. 2019. Kryzys migracyjny 2015+: między solidarnościa a partykularyzmem, Poznań: Wydawnictwo Naukowe Wydziału Nauk Politycznych i Dziennikarstwa.

Reggiardo, A. 2019. Distrust and stigmatization of NGOs and volunteers at the time of the European migrant "crisis". Conflict and implication on social solidarity. Partecipazione e Conflitto. The Open Journal of Sociopolitical Studies 12(2), pp. 460-486. 
Santic, D., Minca, C., Umek, D. 2017. The Balkan Migration Route: Reflections from a Serbian Observatory. In: M. Bobić, S. Janković (eds.). Towards Understanding of Contemporary Migration. Belgrade: University of Belgrade, pp. 221-239.

Save the Children. 2017. Refugee and migrant children injured in illegal border pushbacks across Balkans, https:/www.savethechildren.net/article/refugee-and-migrantchildren-injured-illegal-border-push-backs-across-balkans (accessed 1.01.2019).

Squires, N. 2017. A year on from EU-Turkey deal, refugees and migrants in limbo commit suicide and suffer from trauma, https:/www.telegraph.co.uk/news/2017/03/14/year-eu-turkey-deal-refugees-migrants-limbo-commit-suicide-suffer/ (accessed 3.01.2019).

Stojic Mitrovic, M. 2018. The Reception of Migrants in Serbia: Policies, Practices, and Concepts. Journal of Human Rights and Social Work 4(1), pp. 17-27.

Taylor, L., Cardi, V. 2017. The Smuggling Game, Playing with life and death to reach Europe, http://news.trust.org/shorthand/the-smuggling-game/ (accessed 3.01.2019).

Tondo, L. 2018. Croatia violating EU law by sending asylum seekers back to Bosnia, https://www.theguardian.com/world/2018/dec/17/croatia-violating-eu-law-bysending-back-asylum-seekers-to-bosnia (accessed 1.09.2019).

UNHCR. 2010. Convention and Protocol Relating to the Status of Refugees, https://www. unhcr.org/protect/PROTECTION/3b66c2aa10.pdf (accessed 1.01.2019).

UNHCR. 2019. Serbia, https://www.unhcr.org/see/where-we-work/serbia (accessed 20.11.2019).

UNODC. 2015. World Drug Report, https://www.unodc.org/documents/wdr2015/World Drug_Report_2015.pdf (accessed 1.09.2020).

Voynov, G., Franková, H., Górczyńska, M., Nabergoj, M. 2017. Pushed Back at the Door: Denial of Access to Asylum in Eastern EU Member States, https://www.helsinki.hu/ wp-content/uploads/pushed_back.pdf (accessed 3.01.2019).

Vučić o migrantima: Ukoliko bude potrebno, u Srbiju neće ući niko. 2020, http://rs.n1 info. com/Vesti/a574738/Vucic-o-migrantima-izborima-Obradovicu-Milanovicu.html (accessed 1.09.2020).

Walker, S. 2019. Croatian police use violence to push back migrants, president admits, https://www.theguardian.com/world/2019/jul/16/croatian-police-use-violence-topush-back-migrants-says-president (accessed 1.09.2020).

Zebić, E. 2017. Hrvatska policija odbija odgovornost za smrt djevojčice iz Afganistana, https://www.slobodnaevropa.org/a/afganistan-izbjeglice-djevojcica-poginula-nasinama/28929173.html (accessed 1.01.2019).

Zivanovic, M. 2017. Serbia, Croatia Face Lawsuits Over Migrant Girl's Death, http:// www.balkaninsight.com/en/article/family-of-killed-afghan-girl-to-launch-casesagainst-croatia-and-serbia-12-19-2017 (accessed 1.01.2019).

Zivanovic, M., Vladisavljevic, A., Dimitrov, M., Lakic, M. 2018. Number of Unaccompanied Child Refugees Rises in Balkans, http://www.balkaninsight.com/en/article/number-ofunaccompanied-child-refugees-rises-in-balkans-06-20-2018 (accessed 1.01.2019).

Zuvela, M. 2017. Balkan police break up Turkish migrant smuggling ring, https://www. reuters.com/article/us-europe-migrants-balkans-arrests/balkan-police-break-upturkish-migrant-smuggling-ring-idUSKCN1BP25X?il=0 (accessed 1.01.2019). 